\title{
ПОРІВНЯЛЬНИЙ АНАЛІЗ ПРАВОВОГО РЕГУЛЮВАННЯ БАНКІВСЬКОЇ ТАЄМНИЦІ У КРИМІНАЛЬНОМУ ПРОЦЕСІ УКРАЇНИ, РОСІЙСЬКОЇ ФЕДЕРАЦІЇ ТА РЕСПУБЛІКИ БІЛОРУСЬ
}

Кучерук Г. Л.

У статmі здійснено порівняльний аналіз правового регулювання порядку та підстав отримання інформації, що містить банківську таємницю, шляхом вивчення правового регулювання цих питань у законодавстві України, Російської Федерації та Республіці Білорусь. Виокремлені особливості правового регулювання порядку та підстав отримання інформації, що містить банківську таємницю, в зазначених країнах із метою запозичення позитивного досвіду такого регулювання та реформування законодавства України.

Проаналізовано перелік державних правоохоронних органів зазначених країн, які згідно із законодавством мають право на отримання такої інформації для кожного з цих органів окремо, підстави та порядок для звернення із таким запитом. Розглянуті вимоги, які пред'являються для форми та змісту, яким має відповідати запит правоохоронних органів зазначених у статmі країн щодо отримання інформації, що містить банківську таємницю, у процесі виконання ними своїх владних повноважень при здійсненні кримінального судочинства.

У статmі також розглянуто особливості порядку отримання інформаціі, що містить банківську таємницю, у кримінальному процесі кожної із зазначених країн шляхом проведення слідчої дії - виїмки або обшуку, так із використанням заходу забезпечення кримінального провадження - тимчасового доступу до речей та документів, який по суті є тотожним слідчій дії - виїмці. Проаналізовано порядок та підстави для такого звернення до суду з метою отримання дозволу на проведення таких слідчих дій та здійснення тимчасового доступу до речей та документів і виконання судових рішень.

3 урахуванням аналізу порядку та підстав отримання інформації, що містить банківську таємницю, запропоновано доповнити Кримінальний процесуальний кодекс України окремою главою, який регламентує тимчасовий доступ до речей $і$ документів, що містить охоронювану законом таємницю, де передбачити детальний порядок, підстави отримання інформації, що містить охоронювану законом таємницю, у тому числі інформації, що містить банківську таємницю, з метою уніфікованого регулювання отримання такої інформації в кримінальному судочинстві.
Ключові слова: банківська таємниця, правовий режим банківської таємниці, порядок розкриття банківської таємниці, правоохоронні органи, слідчі (розшукові) діi.

Kucheruk G. L. Comparative analysis of the legal regulation of banking secrecy in the criminal process of Ukraine, the Russian Federation and the Republic of Belarus

The article provides a comparative analysis of the legal regulation of the procedure and grounds for obtaining information containing banking secrecy by studying the legal regulation of these issues in the legislation of Ukraine, the Russian Federation and the Republic of Belarus. Peculiarities of legal regulation of the procedure and grounds for obtaining information containing banking secrecy in these countries in order to learn from the positive experience of such regulation and reform the legislation of Ukraine.

The list of state law enforcement agencies of these countries, which according to the law have the right to receive such information for each of these bodies separately, the grounds and procedure for making such a request. The requirements for the form and content of the request of the law enforcement agencies of the countries referred to in the article to obtain information containing banking secrecy in the course of their exercise of official authority in criminal proceedings are considered.

The article also considers the peculiarities of the procedure for obtaining information containing banking secrecy in the criminal process of each of these countries by conducting an investigative action - seizure or search, and using a measure of criminal proceedings - temporary access to things and documents, which is essentially identical to the investigator. actions - notches. The procedure and grounds for such an appeal to the court, for obtaining permission to conduct such investigative actions and the implementation of temporary access to things and documents and the execution of court decisions are analyzed.

Taking into account the analysis of the procedure and grounds for obtaining information containing banking secrecy, it is proposed to supplement the Criminal

() Кучерук Г. Л., 2020 
Procedure Code of Ukraine with a separate chapter regulating temporary access to things and documents containing legally protected secrets, where to provide detailed procedure the law of secrecy, including information containing bank secrecy for the purpose of unified regulation of obtaining such information in criminal proceedings.

Key words: bank secrecy, legal regime of bank secrecy, the order of disclosing bank secrecy, law enforcement agencies, investigative (search) actions.

Постановка проблеми та її актуальність. Нині немає єдиного підходу законодавців щодо регулювання банківської таємниці в кримінальному процесі, незважаючи на те, що бурхливий розвиток інформаційних відносин та запровадження інформаційних технологій потребує вдосконалення правового регулювання доступу та використання інформації з обмеженим доступом з метою iї використання для ефективної протидії, насамперед, економічної злочинності, яка з кожним роком набуває досконаліших форм та транснаціонального характеру.

Аналіз останніх досліджень та публікацій. 3 огляду на те, що банківська таємниця $є$ міжгалузевим правовим інститутом, питання банківської таємниці та іï правового режиму досліджували у своїх працях представники наукової спільноти у сфері господарського, цивільного, фінансового, адміністративного, кримінально-процесуального права в Україні, Російській Федерації, Республіці Білорусь: А.І. Марущак, Г.О. Світлична, Д.О. Гетманцев, А.В. Сорока, А.О. Шаповалова, С.С. Чернявський, С.Ю. Віцин, П.А. Лупинська, М.М. Агарков, О.Ю. Вікулін, Л.Г. Ефімова, В.Д. Ларічев, О.О. Самсонова, Н.В. Неверова, А.С. Селівановський, Р.Р. Томковіч та інші.

Метою статті $\epsilon$ проведення порівняльноправового дослідження сучасного стану правового регулювання банківської таємниці в кримінальному процесі Російської Федерації та Республіки Білорусь, та порівняння його 3 кримінально-процесуальним законодавством України з метою з'ясування напрямів, за якими триває розвиток кримінально-процесуального законодавства в зазначених країнах у сфері отримання інформації, що містить банківську таємницю, а також вивчення можливості використання виявлених прогресивних тенденцій в українському законодавстві.

Виклад основного матеріалу. У світовій практиці державного регулювання банківської діяльності, зокрема правового режиму банківської таємниці, можна виділити дві основні тенден- ції: одні країни вводять жорсткі заходи державного регулювання та контролю над фінансовими потоками та лібералізацію режиму доступу до такої інформації, а інші відстоюють максимальну недоторканність банківської таємниці. Україна, Російська Федерація та Республіка Білорусь належать до країн, де банківська таємниця позиціонується як публічно-правовий інститут і де інтереси суспільства та держави у процесі охорони банківської таємниці знаходяться на першому місці.

Як слушно зазначає з цього приводу Р.Р. Томкович, захист банківської таємниці не має бути самоціллю, і певні державні органи об'єктивно повинні мати доступ до зазначеної інформації [1, c. 133].

У процесі проведення порівняльного дослідження, на мій погляд, доцільно було б також зазначити, що визначення поняття банківської таємниці у країнах, правове регулювання в яких досліджується у цій статі, відрізняється між собою як у теоретико-науковому, так і законодавчому аспекті.

Так, відомий український вчений Д.О. Гетманцев розглядає банківську таємницю як інформацію про діяльність та фінансовий стан клієнта, яка стала відома банку у процесі обслуговування клієнта та взаємовідносин із ним чи третім особам у процесі надання послуг банку і розголошення якої може завдати матеріальної чи моральної шкоди клієнту [2, с. 75].

Російський вчений О.О. Вікулін пропонує розглядати банківську таємницю як відомості щодо операцій, рахунків і внесків своїх клієнтів і кореспондентів, а також інші відомості, встановлені кредитною організацією в їхніх інтересах, поширення яких може завдати шкоди клієнтам і кореспондентам кредитної організації [3, с. 36].

Білоруській вчений Ю.П. Довнар зазначає, що до банківської інформації варто зараховувати будь-яку інформацію, що виникає в результаті банківської діяльності [4, с. 158].

Історично склалося, що у всьому світі банківська таємниця, з огляду на своє значення, визначається як юридичний принцип, відповідно до якого банки та інші кредитні організації захищають відомості про вклади і рахунки своїх клієнтів і кореспондентів, про банківські операції по рахунках і операціях в інтересах клієнта, розголошення яких може порушити право останніх на недоторканність приватного життя.

Принцип невтручання у приватне життя людини закріплено у ст. 32 Конституції України, за яким не допускається збирання, зберігання, викори- 
стання та поширення конфіденційної інформації про особу без ії̈ згоди, крім випадків, визначених законом, і лише в інтересах національної безпеки, економічного добробуту та прав людини [5].

Конституція Російської Федерації у ст.ст. 23, 24 містить положення про те, що кожен має право на недоторканність приватного життя, особисту и сімейну таємницю. Збір, зберігання, використання та поширення інформації про приватне життя особи без іï згоди не допускаються [6].

Згідно зі ст.ст. 23, 28 Конституції Республіки Білорусь, кожен має право на захист від незаконного втручання в його особисте життя, Обмеження прав і свобод особистості допускається тільки у випадках, передбачених законом, в інтересах національної безпеки, громадського порядку, захисту моральності, здоров'я населення, прав і свобод інших осіб [7].

Однак, незважаючи на гарантовані конституцією зазначених країн права людини та їх захист від незаконного втручання, держава регламентує також підстави та порядок, коли права людини можуть бути обмежені для захисту публічних інтересів. Ці положення регламентовані у відповідних статтях кримінальних процесуальних кодексів України, Російської Федерації та Республіки Білорусь у вигляді завдань кримінального провадження, призначення кримінального судочинства та принципів кримінального процесу.

Отримання у кримінальному процесі інформації, що містить банківську таємницю, пов'язано із використання такої інформації як доказу у кримінальному провадженні та оцінці відповідно до тих вимог, які законодавець пред'являє до них iз точки зору допустимості, належності достовірності та достатності. Ці вимоги $€$ майже всі однаковими щодо їх законодавчої регламентації в кримінальних процесуальних кодексах України, Російської Федерації та Республіки Білорусь (далі - КПК України, КПК РФ, КПК РБ).

Тому у процесі визначення змісту та обсягу таких фактичних даних, які містять банківську таємницю, та можуть бути використані у доказуванні в кримінальному процесі, варто, по-перше, проаналізувати законодавчу регламентацію визначення поняття банківської таємниці.

Аналізуючи наявність в Україні та зазначених державах спеціального законодавства, що регулює правовий режим відомостей, що містять банківську таємницю, варто зазначити, що всі держави приділяють цьому питанню значної уваги шляхом прийняття окремих законодавчих актів, або, включивши до складу законів про банки та банківську діяльність, окремі розділи щодо правового режиму отримання інформації, що містить банківську таємницю, у галузевих нормативних актах, так і у кримінально-процесуальному законодавстві кожної з країн.

У ст. 162 КПК України міститься положення про те, що до охоронюваної законом таємниці, яка міститься у речах і документах, належать відомості, які можуть становити банківську таємницю. Крім того, правовий статус охоронюваної законом таємниці регламентується іншими спеціальними законами України [8].

Кримінально-процесуальне законодавство РБ та РФ не містить прямої регламентації щодо видів охоронюваної законом таємниці, стосовно якої передбачено судовий або інший порядок отримання такої інформації. Види та правовий режим інформації з обмеженим доступом, у тому числі інформації, яка містить банківську таємницю, містять спеціальні закони.

Крім того, з огляду на специфічний характер правового інституту банківської інформації, детальніше визначення та зміст інформації, що містить банківську таємницю, міститься у спеціальних законах та кодексі країн, законодавство яких аналізується у статті. Так, ст. 60 Закону України «Про банки та банківську діяльність» визначає, що інформація щодо діяльності та фінансового стану клієнта, яка стала відомою банку у процесі обслуговування клієнта та взаємовідносин із ним чи третім особам у процесі надання послуг банку, $\epsilon$ банківською таємницею [9].

Банківською таємницеює відомості про банківські рахунки клієнтів, у тому числі кореспондентські рахунки банків у Національному банку України, операції, які були проведені на користь чи за дорученням клієнта, здійснені ним угоди, фінансово-економічний стан клієнтів, системи охорони банку та клієнтів, інформація про організаційно-правову структуру юридичної особи - клієнта, іi керівників, напрями діяльності, відомості стосовно комерційної діяльності клієнтів чи комерційної таємниці, будь-якого проєкту, винаходів, зразків продукції та інша комерційна інформація, інформація щодо звітності по окремому банку, за винятком тієї, що підлягає опублікуванню, коди, що використовуються банками для захисту інформації, інформація про фізичну особу, яка має намір укласти договір про споживчий кредит, отримана під час оцінки їі кредитоспроможності. Інформація про банки чи клієнтів, що збирається під час проведення банківського та валютного нагляду, становить банківську таємницю. Таким 
чином, законодавець дає однозначне визначення банківської таємниці та окреслює обсяг такої інформації, який не дозволяється обмежувати чи, навпаки, розширювати, тобто перелік такої інформації $є$ вичерпним [9].

Ст,. 26 Федерального закону Російської Федерації (далі - Ф3) «Про банки і банківську діяльність», на відміну від ст. 60 Закону України «Про банки та банківську діяльність», не містить дефінітивного визначення поняття банківської таємниці, а обмежується лише переліченням відомостей, які можуть бути надані уповноваженим органам та посадовим особам за наявності відповідних підстав, що стосується попереднього слідства та органів внутрішніх справ [10].

На відміну від регламентації правового режиму банківської таємниці у законодавстві України та Російської Федерації, яка міститься у низці спеціальних законів, у Республіці Білорусь це питання регламентується кодифікованим нормативно-правовим актом - Банківським кодексом Республіки Білорусь (далі - БК РБ).

Поняття банківської таємниці містить ст. 121 БК РБ: «Відомості про рахунки і вклади (депозити), у тому числі про наявність рахунку в банку (небанківської кредитно-фінансової організації), його власника, номер та інші реквізити рахунку, розмір коштів, що знаходяться на рахунках і у вкладах (депозитах), а так само відомості про конкретні угоди, про операції без відкриття рахунку, операції по рахунках і вкладах (депозитах), а також про майно, що знаходиться на зберіганні в банку, $\epsilon$ банківською таємницею і не підлягають розголошенню» [11].

Аналізуючи законодавче визначення банківської таємниці в Банківському кодексі Республіки Білорусь, варто зазначити, що законодавець також пішов шляхом відмови від дефінітивного підходу визначення банківської таємниці.

Суттєвою відмінністю переліку відомостей, що містять банківську таємницю, за законодавством України та Республіки Білорусь від законодавства РФ є те, що перелік відомостей, що містять банківську таємницю, є вичерпним, оскільки ч. 1 ст. 26 ФЗ «Про банки і банківську діяльність» передбачено право кредитно-фінансових установ самостійно визначати відомості, які можуть належати до банківської таємниці [10].

Крім того, аналізуючи перелік відомостей, які визнаються за законодавством банківською таємницею, варто наголосити, що законодавча регламентація переліку таких відомостей, яка міститься в законодавстві України, є ширшою, ніж в аналогічному законі Російської Федерації та Банківському кодексі Республіки Білорусь, оскільки містить ще і персональні дані клієнта та відомості комерційного характеру.

Аналізуючи правовий режим отримання інформації, що містить банківську таємницю, з точки зору допустимості використання у подальшому такої інформації як доказу у кримінальному процесі, слід, по-перше, проаналізувати, яким чином така інформація може бути отримана відповідними суб'єктами владних повноважень.

У ст. 93 КПК України, ст.ст. 21, 86 КПК Російської Федерації та ст. 103 КПК Республіки Білорусь сторона обвинувачення, орган кримінального переслідування здійснюють збирання доказів як шляхом проведення слідчих (розшукових) дій, так і шляхом витребування та отримання від органів державної влади, підприємств, установ та організацій, службових та фізичних осіб речей, документів та відомостей, які мають значення для кримінального провадження (кримінальної справи) шляхом надання відповідного запиту, який, згідно із законом, є обов'язковим для виконання [8; 12; 13].

Аналізуючи порядок витребування та отримання інформації, що містить банківську таємницю, шляхом здійснення процесуальних дій, треба зазначити, що цей порядок детально передбачено спеціальними нормативними законодавчими та підзаконними актами країн, законодавство яких аналізується.

Так, відповідно до пп. 3, 3-1, 3.2 ст. 62 Закону України «Про банки та банківську таємницю» інформація, що містить банківську таємницю, без судового рішення надається органам прокуратури України, Служби безпеки України, Державному бюро розслідувань, Національної поліції, Національному антикорупційному бюро України, Антимонопольного комітету України - на їх письмову вимогу стосовно операцій за рахунками конкретної юридичної особи або фізичної особи - суб'єкта підприємницької діяльності за конкретний проміжок часу, в тому числі із зазначенням контрагентів на вимогу Національному антикорупційному бюро України у справах щодо виявлення необґрунтованих активів та збору доказів їх необґрунтованості в межах їхньої компетенції [9].

Відповідно до положень ст. 62 Закону України «Про банки та банківську діяльність» вимога відповідного державного органу на отримання інформації, яка містить банківську таємницю, має: бути викладена на бланку державного органу встановленої форми або надіслана в електро- 
нному вигляді; бути надана за підписом керівника державного органу (чи його заступника), скріпленого гербовою печаткою, або бути завіреною кваліфікованим електронним підписом керівника державного органу (чи його заступника); містити передбачені цим Законом підстави для отримання цієї інформації; містити посилання на норми закону, відповідно до яких державний орган має право на отримання такої інформації [9].

Банк відмовляє в розкритті інформації, що містить банківську таємницю, якщо за своєю формою або змістом вимога відповідного державного органу не відповідає нормам ч. 2 ст. 62 Закону про банки [14].

Згідно зі ст. 26 Федерального закону (далі Ф3) «Про банки і банківську діяльність» довідки по операціях і рахунках юридичних осіб і громадян, які здійснюють підприємницьку діяльність без створення юридичної особи, фізичних осіб, видаються кредитною організацією за наявності згоди керівника слідчого органу - органам попереднього слідства у справах, що перебувають в їх провадженні. Крім того, згідно із зазначеною статтею, довідки по операціях і рахунках юридичних осіб і індивідуальних підприємців, по операціях, рахунках і вкладах фізичних осіб видаються на підставі судового рішення кредитною організацією посадовим особам органів, уповноважених здійснювати оперативно-розшукову діяльність, у процесі виконання ними функцій щодо виявлення, попередження та припинення злочинів за їхніми запитам, які направляються в суд у порядку, передбаченому ст. 9 Федерального закону від 12 серпня 1995 р. N 144-Ф3 «Про оперативно-розшукову діяльність», за наявності відомостей про ознаки підготовлюваних, скоєних або вчинених злочинів, а також про осіб, що їх підготовляють, які роблять чи які вчинили, якщо немає достатніх даних для вирішення питання про порушення кримінальної справи. Переліки зазначених посадових осіб встановлюються нормативно-правовими актами відповідних федеральних органів виконавчої влади [10].

Це положення закону містить певні протиріччя, оскільки у Федеральному законі N 144-Ф3 від 12 серпня 1995 року «Про оперативно-розшукову діяльність» у жодних формах не передбачено право оперативних підрозділів на отримання інформації, що містить банківську таємницю [15].

Згідно із ч. 3 ст. 121 Банківського Кодексу Республіки Білорусь (далі - БК РБ) у випадках, передбачених законодавчими актами Республіки Білорусь, відомості, що становлять банківську таємницю фізичних осіб, юридичних осіб і індивідуальних підприємців, надаються банком: судам по справах, що перебувають в їх провадженні, прокурору або його заступнику, а також із санкції прокурора чи його заступника органам дізнання і попереднього слідства - по провадженнях за матеріалами і (або) у кримінальних справах, спеціальним підрозділам по боротьбі з корупцією і організованою злочинністю органів внутрішніх справ, підрозділам по боротьбі з економічними злочинами органів внутрішніх справ - із санкції прокурора чи його заступника, органам державної безпеки Республіки Білорусь.

У випадках, передбачених законодавчими актами Республіки Білорусь, в тому числі цим Кодексом, відомості, що становлять банківську таємницю фізичних осіб, за винятком індивідуальних підприємців, надаються банком: судам - по провадженнях у кримінальним справах, за якими відповідно до закону Республіки Білорусь можуть бути застосовані конфіскація майна і (або) інше майнове стягнення, прокурору або його заступнику, а також із санкції прокурора чи його заступника органам дізнання і попереднього слідства - по провадженнях за матеріалами і (або) у кримінальних справах, спеціальним підрозділам по боротьбі 3 корупцією та організованою злочинністю, підрозділам по боротьбі з економічними злочинами органів внутрішніх справ - із санкції прокурора чи його заступника [11].

Аналізуючи зміст ст. 121 БК РБ, можна зробити висновок, що інформація, що містить банківську таємницю, може бути отримана як на стадії проведення дослідчої перевірки, так i на стадії попереднього слідства, оскільки містить формулювання «наявність провадження за матеріалами і (або) у кримінальних справах» як регламентовані підстави для отримання інформації, що містить банківську таємницю, а також надання такої інформації як органам досудового розслідування, так і суб'єктам, які уповноважені на проведення оперативно-розшукової діяльності [11].

Визначення поняття «провадження за матеріалами і кримінальній справі» міститься у ст. 6 КПК РБ як сукупність процесуальних дій і процесуальних рішень, що здійснюються і виносяться у процесі прийняття та розгляду заяв і повідомлень про злочин і прискорене провадження [13].

Деталізація підстав для отримання інформації, що містить банківську таємницю, отримання інформації, що містить банківську таємницю, до порушення кримінального провадження, надання повноважень спеціальним підрозділам по боротьбі 
3 корупцією та організованою злочинністю, підрозділам по боротьбі з економічними злочинами органів внутрішніх справ прямо не передбачена законодавством України, на відміну від законодавства Республіки Білорусь.

Згідно зі ст. 121 БК РБ, відомості, що становлять банківську таємницю, можуть бути надані банком: на підставі оригіналу письмового запиту, підписаного особою, що подає запит на запитувані відомості (керівником державного органу, іншої організації або уповноваженою посадовою особою), який скріплений печаткою державного органу (у разі звернення державного органу) і містить посилання на норми законодавчих актів Республіки Білорусь, що надають цій особі право на отримання такої інформації; на підставі запиту в електронному вигляді із застосуванням програмно-технічних засобів і технологій, що дають змогу підтвердити цілісність і автентичність відбитку документа, що містить посилання на норми законодавчих актів Республіки Білорусь, що надають особі, що подала запит на ці відомості, право на отримання такої інформації [11].

Слід зазначити, що в законодавстві України, на відміну від законодавства Російської Федерації та Республіки Білорусь, встановлені найбільш чіткі вимоги до запиту державного органу на отримання інформації, що містить банківську таємницю.

Аналізуючи суб'єктний склад осіб, які мають право на отримання інформації, що містить банківську таємницю, варто зауважити, що законодавство Республіки Білорусь та Російської Федерації містить посилання на чіткий суб'єктний склад уповноважених органів та посадових осіб, які мають право готувати та санкціонувати такі запити, у тому числі суб'єкти оперативно-розшукової діяльності, а також містить регламентацію чітких підстав для отримання такої інформації шляхом регламентації складів кримінальних злочинів та мети отримання такої інформації. Наприклад це регламентується у ст. 26 ФЗ РФ «Про банки та банківську діяльність», де $\epsilon$ пряме посилання на переліки зазначених посадових осіб, які встановлюються нормативно-правовими актами відповідних федеральних органів виконавчої влади, що має значення для визнання запита як такого, що подано належним суб'єктом та унеможливлює відмову банківської установи щодо надання інформації, що містить банківську таємницю [10].

Також слід зазначити, що в законодавстві Російської Федерації та Республіки Білорусь чітко регламентовані підстави отримання інформації, що містить банківську таємницю, на відміну від законодавства України, що $є$, на мій погляд, великою прогалиною у законодавчому регулюванні та не може сприяти виконанню завдань кримінального процесу.

Як вже зазначалось раніше, перелік відомостей, які можуть бути надані на письмову вимогу правоохоронних органів, який передбачений ст. 62 Закону України «Про банки та банківську діяльність», містить вичерпний перелік інформації та не підлягає розширеному тлумаченню. У випадках, коли правоохоронні органи вимагають будь-яку іншу інформацію, разом із даними, які перелічені у ст. 62 Закону України, відмова банку в їх наданні буде абсолютно законною та обґрунтованою.

Згідно зі ст. 162 КПК України до охоронюваної законом таємниці, яка міститься в речах та документах, належать відомості, що можуть містити банківську таємницю. Тому у разі потреби отримання відомостей, що можуть містити банківську таємницю та яку неможливо отримати шляхом надання письмового запиту до банківської установи, правоохоронні органи мають звернутися до слідчого судді за дозволом про тимчасовий доступ до інформації, що містить банківську таємницю, i, тільки отримавши відповідну ухвалу, звертатися до банку [8].

Згідно зі ст. 131 КПК України тимчасовий доступ до речей та документів $є$ засобом забезпечення кримінального провадження та $\epsilon$ на сьогодні одним із найбільш поширених заходів забезпечення кримінального провадження. Крім того, вказаний захід $\epsilon$ важливим інструментом збору доказової бази у виключних випадках, а саме: коли доступ до такої інформації обмежений правовим режимом їі охорони та коли сторона кримінального провадження зіткнулася з труднощами в зборі доказів, які, зокрема, можуть убачатись в існуванні певних заборон для розголошення даних, або володільці речей та документів відмовляються добровільно надати необхідні докази [8].

Згідно зі ст. 165 КПК України, особа, яка зазначена в ухвалі слідчого судді, суду про тимчасовий доступ до речей та документів як володілець речей або документів, зобов'язана надати тимчасовий доступ до зазначених в ухвалі речей i документів особі, яка зазначена у відповідній ухвалі [8].

Згідно зі ст. 166 КПК України в разі невиконання ухвали про тимчасовий доступ до речей та документів слідчий суддя, суд за клопотанням 

та науково-методичне забезпечення

сторони кримінального провадження, який надано право на доступ до речей і документів на підставі ухвали, має право постановити ухвалу про дозвіл на проведення обшуку [8].

Обшук та огляд речей і документів, які містять інформацію, що становить банківську таємницю, їх тимчасове вилучення під час цих слідчих (розшукових) дій проводяться на підставі ухвали слідчого судді про дозвіл на обшук або огляд володіння особи (далі - ухвала слідчого судді) та в порядку і з дотриманням вимог глави 16 розділу II, ст.ст. 234-237 глави 20 розділу III КПК України, норм Закону про банки, що забезпечують охорону банківської таємниці [8].

Підстави для отримання інформації, що містить банківську таємницю, на стадії дослідчої перевірки міститься у ст. 103 КПК РБ, згідно 3 якою збирання доказів проводиться у процесі вирішення заяв і повідомлень про злочин, прискореного провадження, дізнання, попереднього слідства і судового розгляду шляхом проведення допитів, очних ставок, пред'явлення для впізнання, виїмки, обшуків, оглядів, слідчих експериментів, проведення експертиз та інших процесуальних дій, передбачених цим Кодексом [13].

Положення ст.ст. 209, 210 КПК РБ містять законодавчу регламентацію підстав та порядку проведення обшуку та виїмки, які є схожими за цілями та результатами їх проведення [13].

Ст. 210 КПК РБ також регламентує положення, що про проведення обшуку і виїмки слідчим, органом дізнання виноситься постанова. Постанова про проведення обшуку, а також виїмку документів, що містять державні секрети або іншу охоронювану законом таємницю, має бути санкціонована прокурором або його заступником, за винятком випадків їх проведення за постановою Голови Слідчого комітету Республіки Білорусь, Голови Комітету державної безпеки Республіки Білорусь або осіб, які виконують їхні обов'язки [13].

Відповідно до п. 7 ч. 1 ст. 29 КПК РФ тільки суд, у тому числі в процесі досудового провадження, має право приймати рішення про проведення виїмки предметів і документів, що містять державну або іншу охоронювану федеральним законом таємницю, а також предметів і документів, що містять інформацію про вклади і рахунки громадян у банках та інших кредитних організаціях, де положення про проведення обшуку для отримання інформації, що містить банківську таємницю, не вказано у законі взагалі [12].
Це питання роз'яснено в ухвалі Конституційного Суду Російської Федерації (КС РФ) від 19 січня 2005 р. N 10-0, в якій було визнано, що положення ч. 2 і 4 ст. 182 КПК РФ щодо підстав та порядку проведення обшуку в системі чинного кримінально-процесуального регулювання припускають необхідність прийняття судового рішення про виїмку та вилучення шляхом проведення обшуку предметів i документів, що містять інформацію про вклади і рахунки в банках та інших кредитних організаціях.

При цьому КС РФ у п. 3 мотивувальної частини Ухвали виклав наступну правову позицію: вимога про проведення виїмки предметів і документів, що містять інформацію про вклади і рахунки громадян у банках і інших кредитних організаціях на підставі судового рішення, зумовлена не особливостями проведеної в цих цілях зазначеної слідчої дії, а специфічним характером інформації, що міститься у вилучуваних предметах та документах. Судове рішення в подібних випадках приймається незалежно від того, оформляється їх вилучення як результат виїмки, що проводиться в порядку ст. 183 КПК РФ, або як результат будьякого іншого слідчої дії (у т.ч. обшуку). Відсутність у ст. 182 КПК РФ прямої вказівки на необхідність винесення судового рішення про проведення обшуку з метою вилучення (виїмки) предметів i документів, що містять інформацію про вклади і рахунки в банках і інших кредитних організаціях, не означає, що нею встановлюється інший, ніж передбачений п. 7 ч. 2 ст. 29 цього Кодексу, порядок виїмки та вилучення предметів і документів та допускається можливість відступу від припису, що міститься у ньому, з боку слідчого, прокурора і суду при застосуванні ними ст. 182 КПК РФ [16].

Ст. 164 КПК РФ містить загальні правила проведення слідчих дій, який передбачає підстави та порядок звернення слідчого органу попереднього слідства або дізнавача за погодженням із керівником слідчого підрозділу та прокурора до суду для отримання дозволу суду щодо проведення слідчої дії - виїмки предметів та документів, які містять інформацію щодо вкладів та рахунках громадян у банках та інших кредитних організаціях, а також про проведення обшуку з метою відшукання предметів і документів, які містять банківську таємницю [12].

Ст. 165 КПК РФ містить регламентацію судового порядку отримання дозволу на проведення слідчої дії, а саме: підстави для такого звернення до суду, вимоги до клопотання про надання дозволу на проведення слідчої дії, у тому числі 
виїмки та обшуку, порядок розгляду клопотання та зміст рішень, які приймає суд за результатами розгляду. Більш детальна інформація щодо підстав та порядку проведення обшуку та виїмки, у тому числі інформації, що містить банківську таємницю, міститься у ст.ст. 182-183 КПК РФ [12].

Висновки. Кримінально-процесуальне регулювання отримання інформації, що містить банківську таємницю, передбачено в законодавстві більшості країн та встановлює однаковий зміст і порядок отримання такої інформації на підставі запиту або проведення слідчих дій. Однак у жодній із країн немає уніфікованого підходу та регламентації цього питання у кримінально-процесуальному законодавстві, що викликає різні трактування та підхід у правозастосовній діяльності, оскільки ці питання є предметом регулювання різних галузей права.

Крім того, вважаю за необхідне доповнити Кримінальний процесуальний кодекс України окремою главою, яка б регламентувала тимчасовий доступ до речей i документів, що містять охоронювану законом таємницю, де варто передбачити детальний порядок, чіткі підстави отримання інформації, що містить охоронювану законом таємниці, в тому числі інформації, що містить банківську таємницю, суб'єктний склад такого заходу, з метою уніфікованого регулювання отримання такої інформації в кримінальному судочинстві.

\section{Література}

1. Томкович Р.Р. Банковское право : курс лекций. Минск : Амалфея, 2011. 671 с.

2. Гетманцев Д.О. Банківська таємниця: особливості ії̈ нормативно-правового регулювання в Україні та в законодавстві зарубіжних країн : дис. ... канд. юрид. наук. Київ, 2003. 206 с.

3. Викулин А.Ю. Категории «банковская тайна» и «коммерческая тайна банка», их соотношение. Банковское дело. 1997. N 12. С. 36-40.

4. Довнар Ю.П. Банковское право. Общая часть. Минск : Амалфея. 2006. 310 с.

5. Конституція України від 28 червня 1996 р. URL: https: / /zakon.rada.gov.ua/laws/show/254\%D0\%BA/ 96-\%D0\%B2\%D1\%80\#Text
6. Конституция Российской Федерации от 12 декабря 1993 г. URL: http://publication.pravo.gov.ru/ Document/View/0001202007040001

7. Конституция Республики Белорусь от 24 ноября 1996 г. URL: https://pravo.by/pravovayainformatsiya/normativnye-dokumenty/konstitutsiyarespubliki-belarus/?print=1

8. Кримінально-процесуальний кодекс України від 13 квітня 2012 р. № 4651-VI. URL: https://zakon. rada.gov.ua/laws/show/4651-17\#Text

9. Про банки і банківську діяльність : Закон України від 7 грудня 2000 р. № 2121-III. URL: https:// zakon.rada.gov.ua/laws/show/2268-19\#Text;

10. О банках и банковской деятельности : Федеральный закон РФ от 2 декабря 1990 г. № 395-1. URL: https://fzrf.su/zakon/o-bankah-i-bankovskojdeyatelnosti-n-395-1/;

11.Банковский кодекс Республики Белорусь от 25 октября 2000 г. № 441-3. URL: https: / / kodeksy-by. com/bankovskij_kodeks_rb.htm;

12.Уголовно-процессуальный кодекс Российской Федерации от 18 декабря 2001 г. № 174-Ф3. URL: http://docs.cntd.ru/document/901802257;

13.Уголовно-процессуальный кодекс Республики Белорусь от 16 июля 1999 г. № 295-3. URL: https:// kodeksy.by/ugolovno-processualnyy-kodeks;

14. Про затвердження Правил зберігання, захисту, використання та розкриття банківської таємниці : Постанова Правління Національного Банку України від 14.07.2006 р. № 267. URL: https://zakon.rada. gov.ua/laws/show/z0935-06\#Text;

15. Про оперативно-розыскную деятельность : Федеральний закон РФ от 12 августа 1995 г. № 144Ф3. URL: http://docs.cntd.ru/document/9012676;

16. Определение Конституционного Суда РФ от 19.01.2005 N 10-0 "По жалобе открытого акционерного общества «Универсальный коммерческий банк «Эра» на нарушение конституционных прав и свобод частями второй и четвертой статьи 182 Уголовно-процессуального кодекса Российской Федерации». URL: https://legalacts.ru/doc/opredeleniekonstitutsionnogo-suda-rf-ot-19012005-n-10-o-po/.

Кучерук Г. Л., ад'юнкт кафедри кримінального процесу Національної академії внутрішніх справ 